\title{
Substitution of tenofovir for nucleoside analogues in virologically controlled HIV-infected patients co-infected with hepatitis $C$ virus: TEN-SWITCH
}

\author{
J Grebely1, L Gallagher², E Knight ${ }^{2}$, K Genoway², M Storms ${ }^{3}$, HK Tossonian ${ }^{3}$, \\ M Hosseina ${ }^{3}$, G Showler ${ }^{4}$, JD Raffa ${ }^{5}$, C Fraser ${ }^{4}$, F Duncan ${ }^{6}$ and B Conway*3
}

Address: ${ }^{1}$ National Centre in HIV Epidemiology and Clinical Research, University of New South Wales, Darlinghurst, Australia, ${ }^{2}$ Department of Anesthesiology, Pharmacology and Therapeutics, University of British Columbia, Vancouver, Canada, ${ }^{3}$ Department of Anesthesiology, Pharmacology and Therapeutics, University of British Columbia, Vancouver, British Columbia, Canada, ${ }^{4}$ Cool Aid Community Health Centre, Victoria, British Columbia, Canada, ${ }^{5}$ Department of Statistics and Actuarial Science, University of Waterloo, Waterloo, Ontario, Canada and ${ }^{6}$ Pender Community Health Centre, Vancouver Coastal Health, Vancouver, British Columbia, Canada

* Corresponding author

from Ninth International Congress on Drug Therapy in HIV Infection

Glasgow, UK. 9-13 November 2008

Published: 10 November 2008

Journal of the International AIDS Society 2008, I I (SuppI I):P277 doi:I0.I I86/I758-2652-I I-SI-P277

This abstract is available from: http://www.jiasociety.org/content/I I/SI/P277

(C) 2008 Grebely et al; licensee BioMed Central Ltd.

\section{Background}

Treatment of hepatitis C virus (HCV) in HCV/HIV coinfected patients requires the simultaneous management of two complex regimens, including addressing potential drug interactions between HCV and HIV medications.

\section{Methods}

TEN-SWITCH is a prospective, observational study to evaluate the impact of substituting tenofovir (TDF) for other nucleoside analogues in virologically controlled HIV-infected patients (HIV RNA $<400$ copies/mL) on maintenance of virologic suppression and immune status in HCV/HIV co-infected subjects. Adverse events and HCV treatment uptake following a switch to TDF were also evaluated.

\section{Summary of results}

Among 23 subjects enrolled (mean age 45 years, 83\% male), 44\% were HCV genotype 3, 65\% were receiving methadone and $87 \%$ reported a history of illicit and injection drug use. The median number of previous NRTIs, NNRTIs and PIs were 2 (range: 0-4), 1 (range: $0-2$ ) and 0 (range: 0-4), respectively. Prior to switch, subjects received PI- $(\mathrm{n}=18, \mathrm{LPV} / \mathrm{RTV}=9, \mathrm{IDV} / \mathrm{RTV}=1, \mathrm{SQV} / \mathrm{RTV}$ $=1, \mathrm{ATV} / \mathrm{RTV}=2, \mathrm{ATV}=4)$ or NNRTI-based $(\mathrm{n}=5, \mathrm{EFV}=$
$2, \mathrm{NVP}=3, \mathrm{DLV}=1)$ HAART in combination with either $3 T C / D D I(n=14), A B C / D D I(n=2)$, FTC/DDI $(n=1)$, $3 \mathrm{TC} / \mathrm{d} 4 \mathrm{~T}(\mathrm{n}=4)$, 3TC/AZT $(\mathrm{n}=1)$ or ABC/AZT $(\mathrm{n}=1)$. Median baseline CD4+ count and HIV RNA were 350 (range: 40-999) cells $/ \mathrm{mm}^{3}$ and $<50$ (range: 0-75) copies/ mL. Overall, $100 \%$ and $91 \%$ had HIV-RNA $<400$ copies/ $\mathrm{mL}$ and $<50$ copies $/ \mathrm{mL}$, respectively. Among the 18 subjects having completed 12 months of follow-up, two subjects $(11 \%)$ discontinued TDF following a switch (one due to adverse events, nausea and vomiting likely associated with addition of RTV to unboosted ATV regimen; one due to non-adherence). Two other adverse events that did not require therapy discontinuation were observed (one vertigo, one - nausea with the addition of RTV). At 12 months of follow-up, the median CD4+ count and HIVRNA were 530 (range: 180-999) cells $/ \mathrm{mm}^{3}$ and $<50$ (range: 0-82) copies/mL. At 12 months (intent to treat), $89 \%$ and $83 \%$ had HIV-RNA $<400$ copies/mL and $<50$ copies/mL, respectively. Of 18 subjects, three (17\%) initiated treatment for HCV infection.

\section{Conclusion}

Switching nucleosides in an effective HAART regimen to TDF in preparation for HCV treatment to address potential ribavirin/nucleoside interactions is a safe intervention 
not associated with loss of virologic or immunologic efficacy of the regimen.

Publish with Bio Med Central and every scientist can read your work free of charge

"BioMed Central will be the most significant development for disseminating the results of biomedical research in our lifetime." Sir Paul Nurse, Cancer Research UK

Your research papers will be:

- available free of charge to the entire biomedical community

- peer reviewed and published immediately upon acceptance

- cited in PubMed and archived on PubMed Central

- yours - you keep the copyright

Submit your manuscript here:

http://www.biomedcentral.com/info/publishing_adv.asp 